\title{
Combined influence of river discharge and wind on littoral nematode communities of a river mouth area of Lake Constance
}

\author{
A. Witthöft-Mühlmann · W. Traunspurger · \\ K. O. Rothhaupt
}

\begin{abstract}
The littoral nematode community adjacent to a river mouth (River Schussen) on Lake Constance (Germany) was studied from February 1999 to January 2000 in order to determine the influence of stress resulting from fluctuations in river discharge on local nematode assemblages. Additionally, the influence of wind as a second important stress factor was considered. Six sample sites were chosen, reflecting a gradient of river influence within the broader river mouth area. Nematode communities, varying in a mean range from 121 to $165 \mathrm{ind} / 10 \mathrm{~cm}^{2}$, were found to differ significantly in terms of abundance, feeding type composition and species diversity. Deposit feeders were most abundant at all sites followed by chewers. Deposit feeders were affected mainly by wind events, while
\end{abstract}

\footnotetext{
A. Witthoft Muhlmann ( $\square)$

Institute for Lake Research, Argenweg 50/1, 88085

Langenargen, Germany

e mail: Andre.Witthoeft@onlinehome.de

W. Traunspurger

Animal Ecology, University of Bielefeld, 33615

Bielefeld, Germany

e mail: Traunspurger@uni bielefeld.de
}

\author{
A. Witthoft Muhlmann - K. O. Rothhaupt \\ Institute Limnology, University of Konstanz, 78457 \\ Konstanz, Germany \\ K. O. Rothhaupt \\ e mail: Karl.Rothhaupt@uni konstanz.de
}

species diversity and the occurrence of chewers were influenced mainly by river discharge. The impact of both these stress factors was modified by a third variable, water level. Moderate and high levels of combined habitat stress led to significant changes in community structure. Under conditions of calm weather and low discharge, reduced species diversity and an increased predominance of deposit feeders were observed. In most cases, species diversity was found to be higher under moderate stress conditions, an observation that offers support for Connel's Intermediate Disturbance Hypothesis.

Keywords Habitat stress - Feeding types · Diversity - Spatial pattern - Temporal pattern . Disturbance

\section{Introduction}

Nematodes are one of the most abundant taxa in freshwater benthic communities (Traunspurger 2000). Four of five multicellular animals are nematodes with estimated $10^{5}$ species (Coomans 2000). Freshwater nematode densities can reach up to $3.5 \times 10^{6}$ individuals per $\mathrm{m}^{2}$ (Traunspurger 2002). They play a major role in ecosystem processes like grazing on periphyton assemblages (bacteria, protests, algae, Montagna 1995). Working in terrestrial environments, Bongers (1990) 
developed an environmental monitoring system by classifying nematode communities into colonizers and persisters. Today this Maturity Index (MI) is also used as bioindicator in aquatic benthic assessments (Bongers and Ferris 1999). Summing up, due to their abundance, species richness, ecology, functional morphology (with regard to feeding type), and short life cycles they are able to respond quickly to environmental change, making them ideal subject organisms for ecological studies (Platt and Warwick 1980; Giere 1993; Hakenkamp et al. 2002).

Seasonal and spatial distribution patterns of nematodes are well described for several lakes (Biró 1973; Holopainen and Paasivirta 1977; Prejs 1977b; Bretschko 1984; Strayer 1985; Prejs and Prejs 1992; Raspopov et al. 1996; Traunspurger 1996; Bergtold and Traunspurger 2004; Wu et al. 2004; Michiels and Traunspurger 2005b). However, studies dealing with the nematode communities of river mouth areas are rare (Nalepa and Quigley 1983). The area used for the current study can be described a lenticular aquatic-terrestrial ecotone, sensu Pieczynska (1990), coupling a water body and adjacent riparian system. Ecotonal habitats exhibit great heterogeneity with respect to abiotic and biotic factors due to the import of organic and inorganic components into the transition zone and offer opportunities to test important ecological concepts. River mouth areas represent zones of transition between rivers and pelagic habitats and function as river-lake interfaces. Among external physical factors influencing the littoral benthic community, wind forces are considered to be of strong importance due to generation of waves and consequent resuspension of sediment. In river-lake ecotones, the river discharge is presumed to play a significant further role in shaping the benthic community. In a previous study, we showed that wind and river discharge have a combined impact on the meiofaunal community of a river mouth ecotone, however the strength of both components was highly variable (Witthöft-Mühlmann et al. 2005a). In addition to causing direct mortality and relocation of organisms, disturbance (sensu Connel 1978) by these factors can alter habitat stability, food supply and inter- and intra-specific competition, and thus ultimately affect community composition and species diversity (Petraitis et al. 1989; Death and Winterbourn 1995; Taniguchi and Tokeshi 2004). In the present study, six sample sites were investigated on a monthly basis over a one year-period within a river-lake-ecotone, thus covering a broad potential range of disturbance stress. We investigated the functional diversity of the nematode community in relation to the pattern of local disturbance and distinguished differences in feeding type compositions and species diversity. The following objectives were addressed in detail: (1) Does disturbance caused by wind and/or river discharge alter nematode communities of the river mouth ecotone? (2) Do "unstable" habitat conditions favour colonizers or affect feeding type composition? (3) Is species diversity increased under moderate habitat stress as predicted by the Intermediate Disturbance Hypothesis (Connell 1978)?

\section{Material and methods}

\section{Study area}

Lake Constance is the second largest lake in Central Europe (surface area: $571.5 \mathrm{~km}^{2}$; mean depth: $91 \mathrm{~m}$, max. depth: $254 \mathrm{~m}$, catchment area: $11,487 \mathrm{~km}^{2}$, IGKB 1994) and is located on the northern fringe of the Alps $\left(47^{\circ} 39^{\prime} \mathrm{N}\right)$. This study covers the river mouth of the River Schussen and the adjacent littoral area. The Schussen (discharge: $15.5 \pm 0.15 \mathrm{~m}^{3} / \mathrm{s}$ (mean $\pm \mathrm{SE}$; Hydrological Services Agency Baden Württemberg); catchment area: $790 \mathrm{~km}^{2}$, IGKB 1994) enters the lake on the northern shore and the river mouth is characterized by an extended littoral area (width: $1.2 \mathrm{~km}$, slope: $<0.2 \%$ ). The inflow pattern of the river depends largely on the wind direction, wind speed, and discharge rate. Since the mean wind direction is south-westerly (German Weather Agency DWD), the main inflow angle of the Schussen River is toward the southeast. Based on this prevailing pattern, six sample sites were chosen, representing the area directly in contact with river discharge, an intermediate zone, and a far distant zone (Fig. 1). Further details are given in Witthöft-Mühlmann et al. (2005a). 


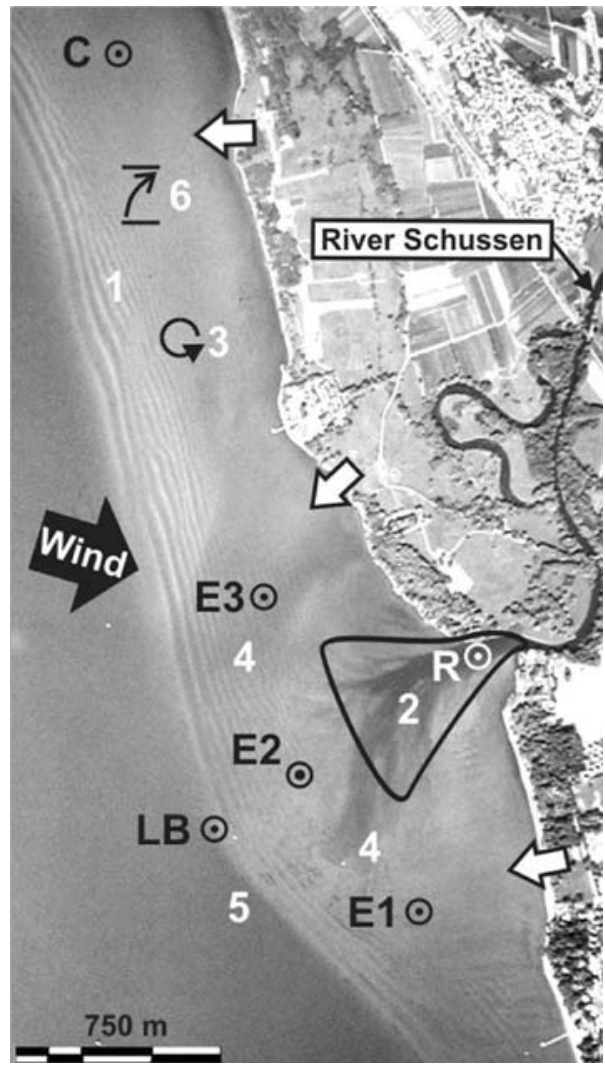

Fig. 1 The littoral zone influenced by the Schussen River at Lake Constance (Germany). Characteristic features, prevailing annual wind direction, and sample sites are shown. Different zones are represented schematically. Sample sites E1 E3 are located within the transition zone of the river mouth, which is adjacent to the littoral area containing samples site $\mathbf{C}$, which presumably experiences low influence of the river. Sample site LB lies on the border of the littoral and pelagic zones and sample site $\mathbf{R}$ is at the river mouth. The aerial view shows the ripples generated by wind action (1), river borne ditches (2), and patches of river borne dissolved and particulate matter (4). Dynamics of wind and river can lead to resuspension of the upper sediment layer (3). Two further important aspects are interactions (e.g., sediment import/export) with the pelagic zone (5) and seasonally changing water level (6). For further details, see Table 1 and the text. The aerial picture was reproduced with kind permission of the German Aerospace Centre

Habitat stress was assumed to be dependent on the strength of the river discharge and wind conditions. Both forces were categorized into classes of low (1), moderate (2), and high stress (3) (Table 1). Low habitat stress is characterized by reduced wave action and/or low river discharge. Moderate conditions mean higher wind
Table 1 Definition of habitat stress resulting from wind strength and river discharge, classified for the month pre ceding each sampling day

\begin{tabular}{|c|c|c|c|}
\hline \multirow[t]{2}{*}{ Force } & \multicolumn{3}{|c|}{ Habitat stress class } \\
\hline & Low & Moderate & High \\
\hline $\begin{array}{l}\text { Wind speed } \geq 7 \mathrm{~m} / \mathrm{s} \\
\text { and duration } \geq 8 \mathrm{~h}\end{array}$ & $\leq 5$ events & 510 events & $>10$ events \\
\hline River discharge & $\leq 10 \mathrm{~m}^{3} / \mathrm{s}$ & $1020 \mathrm{~m}^{3} / \mathrm{s}$ & $>20 \mathrm{~m}^{3} / \mathrm{s}$ \\
\hline
\end{tabular}

speeds and consequent higher waves that can cause the resuspension of sediments, and/or enhanced discharge. High habitat stress is typical of storms and/or high river discharge is characterized by strong sediment erosion and high deposition of river-borne seston. Habitat stress was calculated and classified for the month preceding each sampling day.

\section{Sampling and processing}

Sediment cores (surface area: $26.4 \mathrm{~cm}^{2}$ ) were taken from the study sites using a hand-held corer at monthly intervals from February 1999 through January 2000. Sampling of site LB commenced one month later. At each site, four replicate samples were taken randomly within a rough circle of diameter $8 \mathrm{~m}$. In the laboratory, water overlying the sediment cores was carefully siphoned off, leaving the sediment surface undisturbed. Subsequently, cores were sliced in half longitudinally and photographed in order to document the various sediment layers. One halfcore was then used for meiobenthic processing, while the second half-core was set aside for microbial and chemical analyses. Each half-core was divided into four layers at: 0-13, 14-23, 2453 , and 54-103 mm depth. Prior to chemical and microbial analysis, corresponding depth layers of all four replicate half-cores were pooled.

Meiobenthic fauna were extracted by means of a modified gravity gradient centrifugation technique after Pfannkuche and Thiel (1988) using Ludox AM 40 ${ }^{\mathrm{TM}}$ (DuPont, Inc., Sigma-Aldrich Chemical Co.; colloidal silica, specific density: $\left.1.21 \mathrm{~g} / \mathrm{cm}^{3}\right)$ and preserved in formaldehyde $(4 \%$ final concentration). For counting purposes, each 
processed sample was stained with $1 \%$ RoseBengal. Nematodes were classified into four feeding types: epistrate feeder, deposit feeder, suction feeders and chewers (Yeates et al. 1993; Traunspurger 1997).

Microbial, chemical, and granulometric analyses

A detailed description of the methods applied is given in Witthöft-Mühlmann et al. (2005a). Briefly, algal pigment composition was analysed using a modified HPLC technique after Schmid and Stich (1995). One gram fresh sediment was suspended in $3 \mathrm{ml}$ filtered lake-water $(0.45 \mu \mathrm{m}$, Schleicher \& Schuell OE 67), again diluted 1:100 and then aliquots used for analyses. Bacteria were fixed in $4 \%$ formaldehyde, stained with diamidinophenylindole (DAPI), and then counted directly using epifluorescence microscopy. Total carbon was determined with an infrared analyzer (Leco CS 125) using 200-300 mg dry sediment. Organic carbon was measured after acidification with $\mathrm{HCl}$. Inorganic carbon was calculated as the difference between total and organic carbon. Granulometry of the $<63-\mu \mathrm{m}$ fraction was conducted via Laserparticle sizing (Galai CIS-01; 100-200 mg DW); the $>63-\mu \mathrm{m}$ fraction was obtained by sequential sieving of the sample (6-10 g DW) through mesh sizes of >500-, 250-500-, 126-250-, and 64-125$\mu \mathrm{m}$.

\section{Data analysis}

Univariate diversity indices were calculated with the DIVERSE routine: species number $S$, species richness $d$ (Margalef's index (Clifford and Stephenson 1975)), Shannon-Wiener-Index $H^{\prime}\left(\log _{\mathrm{e}}\right)$ and Evenness $J^{\prime}$. The disturbance/enrichment related MI was calculated according to Bongers (Bongers 1990; Bongers and Ferris 1999). ANOVA was used to test for differences in diversity index values and feeding type abundance between locations and with habitat stress parameters (wind direction and river discharge). Details are given in Table 3. Water level was included as a factor affecting the strength of habitat stress. Season was considered as random effect using the restricted residual maximum likelihood method to fit the present models (Smyth and Verbyla 1996). Whenever model results were significant, Tukey's HSD post hoc test was applied to identify differing means (overall $p$-level 0.05). To fit assumptions for ANOVA, data were $\log +1$ transformed. DIVERSE is a routine of the PRIMER software package V5.2.9 (Primer-E Ltd.). All other procedures were computed with JMP V5.0.1 (SAS Institute Inc.).

\section{Results}

Study sites conditions

River discharge and lake levels fluctuated considerably over the study period, and the site experienced a series of storms with wind speeds $>7 \mathrm{~m} / \mathrm{s}$ (Fig. 2). Increased river discharges often coincided with stormy periods in spring and winter, but not during summer and autumn. The study year had a long period of calm conditions from mid-July to mid-November, whereas the remaining months were marked by alternating periods of moderate and high habitat stress. Lake levels followed a seasonal pattern with strong seasonal fluctuations in water level at the sample sites (maximal range: $2.30 \mathrm{~m}$; Table 2). At the site

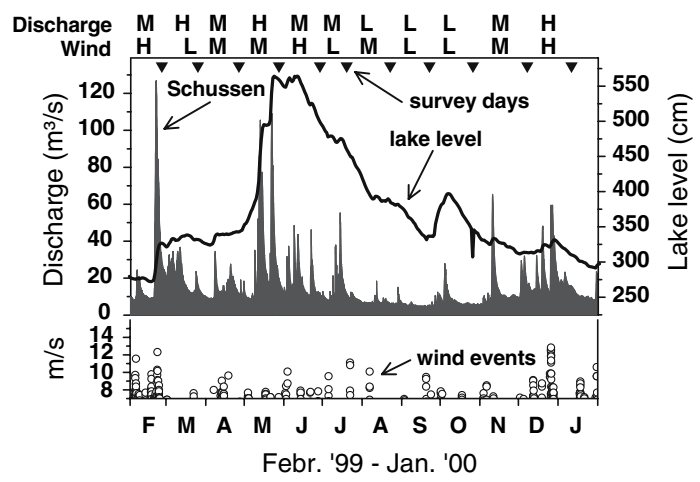

Fig. 2 Schussen River discharge, lake level, and wind events from February 1999 until January 2000. Black line $=$ lake level, grey shading $=$ discharge, open dot $\mathrm{s}=$ hours with wind speed $>7 \mathrm{~m} / \mathrm{s}$, black triangles $=$ sam pling days. $\mathrm{L}=$ low, $\mathrm{M}=$ moderate, and $\mathrm{H}=$ high discharge and wind strength respectively. Sources wind, lake level, and discharge data: German Weather Agency (DWD) \& Environmental Protection Agency Baden Wurttemberg (LUBW) 
nearest to the river mouth (site $\mathrm{R}$ ) the mean organic carbon content was 3.8- to 7-fold (3.47\%) and the mean bacteria concentration 1.9- to 2.7fold higher $\left(4.6 \times 10^{9}\right.$ cells $/ g$ DW; $p<0.0001$, Tukey's HSD) than those recorded at all other sites. Organic carbon levels varied significantly between sites (Table $3 \mathrm{a}, \mathrm{b}$ ). Mean algal pigment concentration was $47-126 \%$ higher at the remote site C (43.1 $\mu \mathrm{g} / \mathrm{g} \mathrm{DW})$. All sites are characterized as fine-sandy according to mean grain size. In general, the range and variability of all parameters was highest at site $\mathrm{R}$ (Table 2).

Nematode community pattern

Mean annual abundance of nematodes ranged from $121 \mathrm{ind} / 10 \mathrm{~cm}^{2}$ (site E1) to $165 \mathrm{ind} / 10 \mathrm{~cm}^{2}$ (site C; Table 2) and nematodes were the prevailing taxon of the meiobenthic community (49.2\%, site C to $71.4 \%$; site LB). Altogether 106 species were identified and recorded. Deposit feeders dominated at all sites in terms of abundance $(58-81 \%)$ followed by chewers $(12-35 \%)$ and epistrate feeders (3-11\%). Suction feeders were rare $(1-4 \%)$. The differences between sites were significant with respect to total nematode abundance and for abundance of epistrate feeders and chewers, but not for deposit feeders (Table 3). No site differed completely from the others. Table 4 summarizes the dominant species categorized according to feeding type.

Mean annual values for univariate diversity measures varied significantly between sites with exception of Margalef's species richness $d$ (Table 3). The Shannon-Wiener diversity index $H^{\prime}$ was significantly lower at river mouth site $\mathrm{R}$ $\left(H^{\prime}=1.17\right)$ than at sites E1-E3 and the remote site $\mathrm{C}\left(H^{\prime}=1.51-1.53\right)$. Species number $S$ was highest at site $\mathrm{R}$, but the community was characterized by just a few dominant species (Evenness $\left.J^{\prime}=0.56\right)$. Species richness and MI varied within a narrow range at all sites $(d=6.8-8.2$; $\mathrm{MI}=2.2-$ 2.4). Seasonal variation in species diversity indices was strong with higher values in spring and lower values in autumn, with exception of site $\mathrm{C}$ where seasonality was less pronounced (Fig. 3). Margalef's species richness and the ShannonWiener-Index increased substantially in spring at the river mouth site R. No clear seasonality was 
Table 3 ANOVA, model results; $H^{\prime}=$ Shannon Wiener Index, $J^{\prime}=$ Evenness, $S=$ species number, $d=$ species richness, $\mathrm{MI}=$ Maturity Index, $\mathrm{C}_{\mathrm{org}}=$ organic carbon

\begin{tabular}{|c|c|c|c|c|c|c|c|}
\hline \multirow{2}{*}{$\begin{array}{l}\text { Depen dent } \\
\text { variable }\end{array}$} & \multirow[t]{2}{*}{ Global effect } & \multicolumn{6}{|l|}{ Effect tests } \\
\hline & & Site & $\begin{array}{l}\text { Water } \\
\text { level }\end{array}$ & Wind & Discharge & $\begin{array}{l}\text { Water } \\
\text { level } \times \text { wind }\end{array}$ & $\begin{array}{l}\text { Water } \\
\text { level } \times \text { discharge }\end{array}$ \\
\hline Nema todes & $\begin{array}{c}r^{2}=0.33 ; F=6.68 \\
P<0.0001\end{array}$ & $P=0.0001$ & $P=0.059$ & $P=0.013$ & $P=0.59$ & $P=0.053$ & $P=0.011$ \\
\hline $\begin{array}{l}\text { Epistrate } \\
\text { feeders }\end{array}$ & $\begin{array}{c}r^{2}=0.41 ; F=9.29 \\
P<0.0001\end{array}$ & $P \leq 0.0001$ & $P=0.46$ & $P=0.28$ & $P=0.078$ & $P=0.88$ & $P=0.74$ \\
\hline $\begin{array}{l}\text { Deposit } \\
\text { feeders }\end{array}$ & $\begin{array}{c}r^{2}=0.42 ; F=9.69 \\
P<0.0001\end{array}$ & $P=0.17$ & $P=0.09$ & $P=0.005$ & $P=0.055$ & $P=0.011$ & $P=0.009$ \\
\hline Chewer & $\begin{array}{l}r^{2}=0.43 ; F=10.04 \\
\quad P<0.0001\end{array}$ & $P \leq 0.0001$ & $P=0.66$ & $P=0.39$ & $P=0.044$ & $P=0.38$ & $P=0.36$ \\
\hline$H^{\prime}$ & $\begin{array}{l}r^{2}=0.50 ; F=13.60 \\
\quad P<0.0001\end{array}$ & $P \leq 0.0001$ & $P=0.40$ & $P=0.44$ & $P=0.03$ & $P=0.99$ & $P=0.66$ \\
\hline$J^{\prime}$ & $\begin{array}{l}r^{2}=0.41 ; F=9.21 \\
\quad P<0.0001\end{array}$ & $P \leq 0.0001$ & $P=0.024$ & $P=0.41$ & $P=0.22$ & $P=0.33$ & $P=0.73$ \\
\hline$S$ & $\begin{array}{l}r^{2}=0.48 ; F=12.22 \\
\quad P<0.0001\end{array}$ & $P=0.025$ & $P=0.11$ & $P=0.32$ & $P=0.028$ & $P=0.34$ & $P=0.84$ \\
\hline$d$ & $\begin{array}{l}r^{2}=0.42 ; F=9.45 \\
\quad P<0.0001\end{array}$ & $P=0.09$ & $P=0.3$ & $P=0.5$ & $P=0.054$ & $P=0.04$ & $P=0.15$ \\
\hline MI & $\begin{array}{l}r^{2}=0.55 ; F=16.25 \\
\quad P<0.0001\end{array}$ & $P \leq 0.0001$ & $P=0.98$ & $P=0.42$ & $P \leq 0.0001$ & $P=0.032$ & $P=0.21$ \\
\hline $\mathrm{C}_{\text {org }}$ & $\begin{array}{l}r^{2}=0.66 ; F=27.16 \\
\quad P<0.0001\end{array}$ & $P \leq 0.0001$ & $P=0.005$ & $P \leq 0.0001$ & $P=0.011$ & $P=0.067$ & $P=0.06$ \\
\hline
\end{tabular}

Italicized values indicate significant difference; $n=243$ (number of samples)

Table 4 The relative abundance of the three most dominant species categorized according to feeding type, respectively

$S=$ number of found species, $\mathrm{SD}=$ standard deviation

\begin{tabular}{llcc}
\hline Feeding type & Dominant species & $S$ & Relative density $(\% \pm$ SD) \\
\hline Epistrate feeders & Ethmolaimus pratensis & 13 & $5.2 \pm 7.7$ \\
& Prodesmodora circulata & & $0.35 \pm 1.15$ \\
& Chromadorita leuckarti & & $0.16 \pm 0.77$ \\
Deposit feeders & Monhystera stagnalis/paludicola & 49 & $32.3 \pm 21.8$ \\
& Daptonema dubium & & $28.4 \pm 20.6$ \\
& Eumonhystera filiformis & & $1.17 \pm 2.73$ \\
Chewers & Tobrilus medius & $17.5 \pm 12.0$ \\
& Tobrilus gracilis & & $5.1 \pm 7.6$ \\
& Tobrius stefanskii & $27.4 \pm 5.0$ \\
Suction feeders & Dorylaimus stagnalis & $0.55 \pm 1.69$ \\
& Mesodorylaimus spec. & & $0.12 \pm 0.57$ \\
& Aporcelaimus spec. & & $0.03 \pm 0.23$ \\
\hline
\end{tabular}

evident in the MI, which decreased continuously at all sites until autumn, followed by a slight increase during winter.

Influence of water level, wind field and river discharge on the nematode communities

Wind events and water level affected the abundance of nematodes in general and of deposit feeders in particular. Abundances of both groups were lowest when habitat stress caused by wind events was high (nematodes: low $=144 \pm 95.9$, moderate $=165.3 \pm 123, \quad$ high $=114.7 \pm 101.7$ ind. $/ 10 \mathrm{~cm}^{2} \pm \mathrm{SD}$; deposit feeders: low $=$ $109.9 \pm 77.7$, moderate $=111.6 \pm 115.1$, high $=$ $67.3 \pm 61.2$ ind. $/ 10 \mathrm{~cm}^{2} \pm \mathrm{SD}$ ) and increased with rising water level. Furthermore, water level had a significant influence on wind and discharge effects (Table 3). Conversely increasing river discharge increased the abundance of chewers (low $=24.7 \pm 22.8, \quad$ moderate $=36.9 \pm 28.6$, high $=46.2 \pm 48.8$ ind. $/ 10 \mathrm{~cm}^{2} \pm \mathrm{SD}$ ) but water 

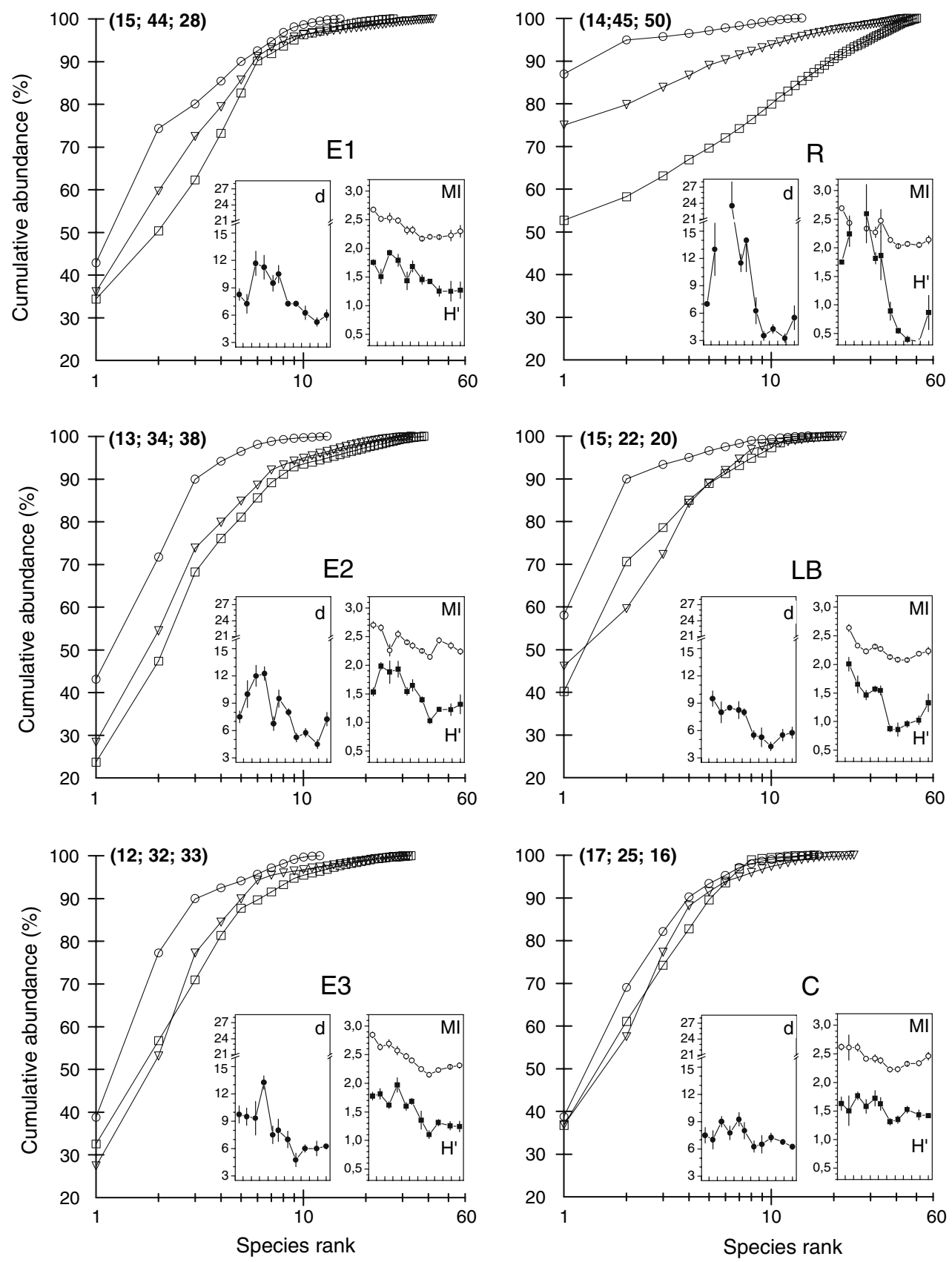

Fig. 3 Site specific diversity patterns. Cumulative relative abundance curves in dependence of low (circles), moder ate (triangles) and high discharge (squares; comp. Fig. 2). $X$ axis $=\log _{10}$ scale. Embedded graphs illustrate seasonal

change in species richness $(d)$, Shannon Wiener Index $\left(H^{\prime}\right)$ and Maturity Index (MI). Numbers in parentheses refer to number of species with increasing discharge (L; M; H). Bars = standard error $(n=4)$

level or its interaction with habitat stress was not significant. The abundance of both feeding types differed significantly between low and moderate stress. The relative abundance of deposit feeders was highest when sites were

exposed to low river discharge and calm wind conditions or high stress resulting from high discharge and strong wind effects. The relative abundance of chewers increased when river discharge was high and wind events were moderate. 
Table 5 Mean values of relative abundance of feeding types and Shannon Wiener diversity index $\left(H^{\prime}\right)$ differentiated according to increasing wind and discharge stress

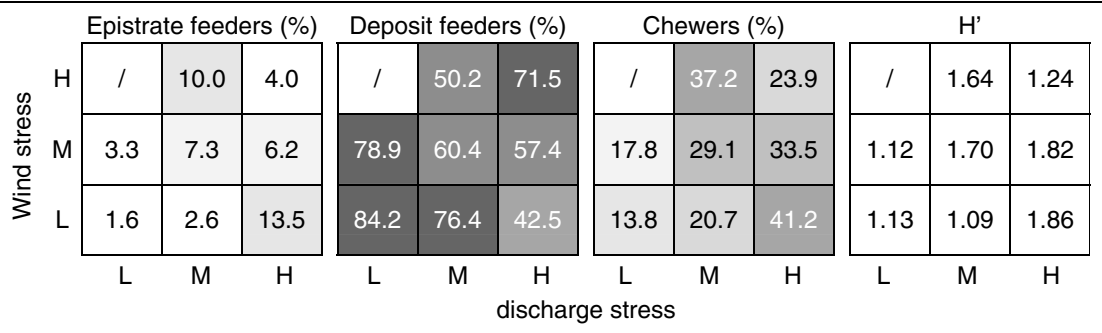

$\mathrm{L}=$ low, $\mathrm{M}=$ moderate, and $\mathrm{H}=$ high stress (comp. Table 1). Grey gradient: $05 \%$ (white), $510 \%, 1015 \%, 1525 \%, 25$ $35 \%, 3545 \%, 4565 \%,>65 \%$ relative abundance; / = combination did not occur

Epistrate feeders showed a similar pattern to chewers (Table 5).

Diversity indices and MI differed significantly between sites and were strongly affected by river discharge but not by wind events. Species diversity increased with increasing river discharge $\left(H^{\prime}\right.$ : low $=1.13 \pm 0.34$, moderate $=1.54 \pm 0.37$, high $=$ $1.63 \pm 0.46 ; S$ : low $=5.9 \pm 1.7$, moderate $=8.2 \pm$ 2.8 , high $=9.0 \pm 4.0$; MI: low $=2.18 \pm 0.11$, moderate $=2.41 \pm 0,21$, high $=2.43 \pm 0.20)$. Evenness was significantly reduced by rising water levels when discharge was low. Interaction between water level and habitat stress played a minor role. Annual variation of Shannon-Wiener species diversity differed between sites. $H^{\prime}$ altered greatly at site $\mathrm{R}$ and at the remote site $\mathrm{C}$ least (Fig. 3). Cumulative dominance plots differed in dependence of discharge stress and revealed three groups of sites. Dominance was strongest at site $\mathrm{R}$, where under low stress only one species accounted for $88 \%$ of the entire assemblage. This dominance fell to $45-50 \%$ under conditions of moderate and high stress. Dominance was weakest at the remote site $\mathrm{C}$, where the influence of habitat stress was marginal. The remaining sites E1-E3 and $\mathrm{LB}$ represent an intermediate group, in which a few species were dominant under low stress conditions, but less so under moderate and high stress (Fig. 3). In all cases, species number was lowest when discharge was low and highest under moderate discharge. A combination of intermediate wind and discharge stress yielded significantly higher species diversity $\left(H^{\prime}\right)(p<0.0001$, Tukey's HSD; Table 5).

\section{Discussion}

The study revealed that (1) the abundance of nematodes in general and deposit feeders in particular were influenced by the strength of wind events, (2) the overall diversity and abundance of chewers are mainly affected by discharge stress, (3) the benthic organic matrix, represented by organic carbon content, was influenced by both forces and (4) changing water levels modified the impact of both wind events and river discharge on the community.

General composition of nematode communities

With 106 species identified, the study area is one of the most species rich freshwater habitats studied thus far. Michiels and Traunspurger (2005a) described 152 species in the littoral area of Lake Obersee, but in most other studies of littoral habitats the number of species recorded is below 50 (Table 6). Species number was highest at the most heterogeneous site $\mathrm{R}$, followed by sites E1-E3 and lower at the remote site $\mathrm{C}$ and the deeper site LB. Hence, species numbers decrease with decreasing influence of the river. Thus our sample sites are seen to provide an accurate representation the transition zone from the river to the lake. However, this pattern was not repeated by the pattern of Shannon-Wienerspecies diversity, which indicated the greatest diversity in sites E1-E3 and the remote site C. The dominance of three species (Daptonema 
Table 6 Compilation of diversity indices in shallow zones of lakes and estuaries with different trophy

\begin{tabular}{|c|c|c|c|c|c|c|}
\hline Lake/Estuary & Trophy & Depth (m) & $S$ & $H^{\prime}$ & MI & Authors \\
\hline Char & Oligotrophic & $<3$ & 21 & 2.42 .7 & & Prejs $^{a}$ \\
\hline Zielony Gasienicowy & Oligotrophic & 69 & 79 & 1.72 .0 & & Prejs ${ }^{b}$ \\
\hline Konigssee & Oligotrophic & 15 & 4851 & 1.02 .1 & & Traunspurger \\
\hline 11 alpine lakes & Oligotrophic & $<2$ & 2475 & 1.73 .6 & & Michiels ${ }^{\mathrm{h}}$ \\
\hline 3 swedish lakes & Oligotrophic & $<2$ & 1422 & 1.52 .0 & & Peters $^{j}$ \\
\hline Lake Constance & Oligo /mesotrophic & $0.5 \quad 4.2$ & 3171 , total: 106 & 1.21 .5 & 2.22 .4 & This study \\
\hline Zarnowieckie & Mesotrophic & $<3$ & 16 & 2.8 & & Prejs $^{\mathrm{a}}$ \\
\hline 8 swedish lakes & Mesotrophic & $<2$ & 1133 & 1.22 .1 & & Peters $^{\mathrm{j}}$ \\
\hline Neusiedlersee & $\begin{array}{l}\text { Thalassohyalin, } \\
\text { meso/eutrophic }\end{array}$ & $<3$ & 26 & 0.12 .0 & & Schiemer $^{\mathrm{d}}$ \\
\hline Obersee & Eutrophic & 1 & 152 & & & Michiels ${ }^{\mathrm{i}}$ \\
\hline Czarna Kuta & Eutrophic & 2.53 .0 & 3 & 0.91 .2 & & Prejs ${ }^{b}$ \\
\hline Donghu & Eutrophic & 2.2 & 720 & 1.02 .1 & 2.63 .3 & $\mathrm{Wu}^{\mathrm{e}}$ \\
\hline Mikolajskie & Eutrophic & $<3$ & 52 & 2.32 .4 & & Prejs $^{a}$ \\
\hline Smolak & Eutrophic & 4.5 & 2 & 0.30 & & Prejs ${ }^{b}$ \\
\hline 6 swedish lakes & Eutrophic & $<2$ & 834 & 1.02 .9 & & Peters $^{j}$ \\
\hline Ems estuary & Eutrophic & Estuary & & & 1.42 .5 & $\operatorname{Essink}^{\mathrm{f}}$ \\
\hline Gironde Estuary & Eutrophic & Estuary & & & 1.6 & Soetart ${ }^{\mathrm{g}}$ \\
\hline
\end{tabular}

${ }^{\mathrm{a}}$ Prejs (1977a), ${ }^{\mathrm{b}}$ Prejs (1977b), ${ }^{\mathrm{c}}$ Traunspurger (1991), ${ }^{\mathrm{d}}$ Schiemer (1978), ${ }^{\mathrm{e}} \mathrm{Wu}$ et al. (2004), ${ }^{\mathrm{f}}$ Essink and Keidel (1998),

${ }^{\mathrm{g}}$ Soetart et al. (1995), ${ }^{\mathrm{h}}$ Michiels and Traunspurger (2005a), ${ }^{\mathrm{i}}$ Michiels and Traunspurger (2004), ${ }^{\mathrm{j}}$ Peters (2005)

$S$, Species number; $H^{\prime}$, Shannon Wiener Index, MI, Maturity Index. All $H^{\prime}$ values calculated as log base e. Values given in the studies of Schiemer and Peters have been transformed

dubium, Monhystera stagnalis/paludicola, and Tobrilus medius) resulted in low evenness scores. The combination of high species numbers and dominance of only few species has previously been described as characteristic of lotic habitats (Beier and Traunspurger 2003). The MI, calculated as a measure of pollution was $>2.0$ at all sites, indicating comparatively low levels of pollution (Beier and Traunspurger 2003). The study revealed significant differences in feeding type composition between all sites with regard to epistrate feeders and chewers, but not to deposit feeders, which were well represented at all sites. This outcome may be indicative of the role of deposit feeders as colonizers, able to recover quickly after disturbance events in dynamic environments (Death and Winterbourn 1995).

Influence of wind effects and river discharge on nematode community structure

In a previous study at the same investigation site, we were able to show that deposition of river borne benthic particulate matter (rBPM) is a function of primary settlement of matter suspended in by river discharge, and subsequent resuspension, resettlement and relocation of abiotic matter and organisms under the influence of wind events (Witthöft-Mühlmann et al. 2005a). The littoral area can switch within days or even hours from one set of more or less stable physical habitat conditions to another. The import of lotic species and relocation of littoral nematodes by the river may result in increased inter- and intraspecific competition between members of the in situ community and relocated organisms. The same mechanism can also influence resource allocation within the entire river mouth area, as observed in the case of organic carbon. However, we were unable to estimate the degree to which passive recruitment contributes to the species diversity observed.

The results of this study have refined our understanding of river-lake interfaces. Wind events were important with regard to abundance of nematodes and in particular to deposit feeders, whereas species measures and the occurrence of chewers were influenced mainly by river discharge. Water level influenced the benthic assemblages generally. The littoral area undergoes large diurnal and seasonal changes in temperature. However, previous analyses indicated that this 
parameter played only a minor role as stress factor (Witthöft-Mühlmann et al. 2005a).

Disturbance is known to alter species diversity in benthic communities (Peterson 1996; Schratzberger and Warwick 1999; Tolonen et al. 2001). Decreasing evenness resulting from rising water levels led to a shift in the nematode community towards few deposit feeders like Monhystera stagnalis/paludicola and Daptonema dubium, both of which have relatively short life cycles. Annual mean nematode abundances were relatively similar at all sites investigated. However, periods of low habitat stress, with calm wind conditions and low discharge, were linked with greater nematode abundance, a strong dominance of deposit feeders and low species diversity. Deposit feeders comprise both selective and non-selective species, feeding on bacteria and unicellular eucaryotes. In this group, reproduction rates are high. The importance of habitat stability and, indirectly, of water level, was demonstrated by the results from the littoral border site LB. This site is located $1 \mathrm{~m}$ deeper than all the others, and was thus less prone to resuspension of sediment by wave action. Here, deposit feeders remained very abundant under any stress condition. Stable conditions may enhance reproductive fitness of deposit feeders and inter-specific competition may be increased, reducing species diversity and evenness. Conversely, species diversity and the proportions of chewers and epistrate feeders all increased under conditions of moderate and high stress, with river discharge as the major driving factor. In a previous microcosm experiment using river-borne benthic particulate matter of the Schussen, we could show that increased rBPM can have a suppressive effect, especially on chewers (Witthöft-Mühlmann et al. 2005b). Concentration of rBPM is higher when discharge is low. These field results support our previous experimental findings.

According to Allan (1995) and Tokeshi (1993), abiotic factors and physical disturbance can weaken biological interactions. However, the four month-long calm period encountered during the investigation may have allowed the communities to equilibrate and given colonizers like deposit feeders an advantage over persisters such as chewers. Death and Winterbourn (1995) found maximum species richness at sites of greatest stability, and maximum evenness at sites of intermediate stability. They stressed that high species diversity can be maintained by habitat patchiness. The results of mescosm experiments of Austen et al. (1998) were consistent with Intermediate Disturbance Hypothesis (Connell 1978) and the authors suggested that dominance of few species, as it is the case in our study, is important in maintaining regional diversity. Our results agree with this study, in that species diversity $\left(H^{\prime}\right)$ and species number $(S)$ were reduced when wind stress and discharge stress were either both low and both high. Conversely, any other combination of stresses may enhance habitat patchiness. Urban (2004) showed in a freshwater-pond study that coping with local environmental heterogeneity requires trade offs between adaptations that increase environmental tolerance and those that promote fitness within intense biotic interactions. Such trade offs will often regulate metacommunity dynamics. Our results provided hints that these trade offs might vary along a disturbance gradient such as that within a river-lake interface.

\section{Conclusion}

The results obtained describe the broader river mouth area as a very dynamic, relatively unpolluted benthic habitat, representing a transition from riverine to fully littoral habitat with no river influence. Within this ecotone, the composition of nematode feeding types differed significantly between sample sites with the most pronounced differences recorded for the site closest to the river mouth. Consideration of habitat stress classes has improved understanding of the processes involved in regulating the composition of nematode communities. Disturbance or stress resulting from wind and river discharge regulated habitat patchiness and thereby led to changes in community composition. The impacts of wind and discharge are in turn regulated by water level. Low stress led to greater nematode abundance, reduced species diversity, and an increased dominance of deposit feeders, thus colonizers were in favour under more stable habitat conditions. The 
results support the Intermediate Disturbance Hypothesis.

Acknowledgements We thank Simone Eckenfels and Petra Heim for help with microbial analyses and sample processing, Susanne Fitz and Viola Burkhard Gehbauer for help with water chemistry analyses, Barbara Haibel for determining phytobenthos, Nicola Reiff for preparing nematodes, and Alexander Brinker for statistical advice. The manuscript has benefited from the comments of Alexander Brinker, Hans Gude, and Tom Moens. This research is part of a dissertation to be submitted to the University of Constance by A. Witthoft Muhlmann, funded by the German Research Foundation (Special Collaborative Research Programme 454 "Littoral of Lake Constance").

\section{References}

Allan JD (1995) Structure and function of runnings waters. Chapman \& Hall, London, p 388

Austen M, Widdicombe S, Villano Pittaco N (1998) Effects of biological disturbance on diversity and structure of meiobenthic nematode communities. Mar Ecol Prog Ser 174:233 246

Beier S, Traunspurger W (2003) Seasonal distribution of free living nematodes in the Krahenbach, a fine grained submountain carbonate stream in southwest Germany. Nematology 5:113 136

Bergtold M, Traunspurger W (2004) The benthic commu nity in the profundal of Lake Brunnsee: seasonal and spatial patterns. Arch Hydrobiol 160:527 554

Biró K (1973) Nematodes of Lake Balaton. IV. Seasonal qualitative and quantitative changes. Annl Inst Biolog ici (Tihany) Hungaricae Acad Scientiarum 40:135 158

Bongers T (1990) The maturity index: an ecological measure of environmental disturbance based on nematode species composition. Oecologia 83:14 19

Bongers T, Ferris H (1999) Nematode community struc ture as a bioindicator in environmental monitoring. Environmental Toxicology and Chemistry 14:224 228

Bretschko G (1984) Free living nematodes of a high mountain lake (Vorderer Finstertaler See, Tyrol, Austria, $2237 \mathrm{~m}$ asl). I. Monhystera cf. stagnalis and Ethmolaimus pratensis. Arch Hydrobiol 101:39 72

Clifford HT, Stephenson W (1975) An introduction to numerical classification. Academic Press, New York, xii $+229 \mathrm{p}$

Connell JH (1978) Diversity in tropical rain forests and coral reefs. Science 199:1302 1310

Coomans A (2000) Nematode systematics: past, present and future. Nematology 2:3 7

Death RG, Winterbourn MJ (1995) Diversity patterns in stream benthic invertebrate communities: the influ ence of habitat stability. Ecology 76:1446 1460

Essink K, Keidel H (1998) Changes in estuarine nematode communities following a decrease of organic pollu tion. Aquat Ecol 32:195 202
Giere O (1993) Meiobenthology the microscopic fauna in aquatic sediments. Springer, Berlin, p 328

Hakenkamp CC, Morin A, Strayer DL (2002) The functional importance of freshwater meiofauna. In: Rundle S, Robertson AL, Schmid Araya MJ (eds) Freshwater Meiofauna: biology and ecology. Back huys Publishers, Leiden, The Netherlands, pp 321335

Holopainen IJ, Paasivirta L (1977) Abundance and biomass of the meiozoobenthos in the oligotrophic and mesohumic Lake Paarjavi, southern Finland. Annl Zool Fennici 14:124 134

IGKB (1994) Limnologischer Zustand des Bodensees, 160

Michiels IC, Traunspurger W (2004) A three year study of seasonal dynamics of a zoobenthos community in a eutrophic lake. Nematology 6:655 669

Michiels IC, Traunspurger W (2005a) Benthic community patterns and the composition of feeding types and reproductive modes in freshwater nematodes. Nema tology 7:21 36

Michiels IC, Traunspurger W (2005b) Seasonal variation of biodiversity and assemblage structure in freshwater nematodes. Arch Hydrobiol 163:183 194

Montagna PA (1995) Rates of metazoan meiofaunal microbivory: a review. Vie Milieu 45:1 9

Nalepa TF, Quigley MA (1983) Abundance and biomass of the meiobenthos in nearshore Lake Michigan with comparisons to the macrobenthos. J Great Lakes Res 9:530 547

Peters L (2005) Species distribution of free living nema todes and other meiofauna in littoral periphyton communities of lakes. Nematology 7:267 280

Peterson CG (1996) Response of benthic algal communi ties to natural physical disturbance. In: Stevenson RJ, Bothwell MI, Lowe RL (eds) Algal ecology: freshwa ter benthic ecosystems. Academic press, San Diego, pp 375402

Petraitis PS, Latham RE, Niesenbaum RA (1989) The maintenance of species diversity by disturbance. Quart Rev Biol 69:393 418

Pfannkuche O, Thiel H (1988) Sample processing. In: Higgins RP, Thiel H (eds) Introduction to the study of meiofauna. Smithsonian Institution Press, Washing ton D.C., pp 134145

Pieczynska E (1990) Lentic aquatic terrestrial ecotones: their structure, functions, and importance. In: Naiman RJ, Décamps $\mathrm{H}$ (eds) Ecology and management of aquatic terrestrial ecotones. UNESCO, Paris, pp 103 140

Platt HM, Warwick RM (1980) The significance of free living nematodes to the littoral ecosystem. In: Price $\mathrm{JH}$, Irvine DEG, Farnham WF (eds) The shore environment, vol. 2, Ecosystems. Academic Press, London and New York, pp 729759

Prejs K (1977a) The littoral and profundal benthic nem atodes of lakes with different trophy. Ekologia polska 25:21 30

Prejs K (1977b) The species diversity, numbers and biomass of benthic nematodes in central part of lakes with different trophy. Ekologia polska 25:31 44 
Prejs K, Prejs A (1992) Importance of predation in regulating density of meio and macrofauna in sea sonal tropical waters. Hydrobiologia 242:77 86

Raspopov IM, Andronikova IN, Dotsenko ON, Kurashov EA, Letanskaya GI, Panov VE, Rychkova MA, Telesh IV, Tchernykh OA, Vorontsov FF (1996) Littoral zone of Lake Ladoga: ecological state eval uation. Hydrobiologia 322:39 47

Schiemer F (1978) Verteilung und Systematik der freile benden Nematoden des Neusiedlersees. Hydrobiolo gia 58:167 194

Schmid H, Stich HB (1995) HPLC analysis of algal pigments: comparisons of columns, column properties and eluents. J Appl Phycol 7:487 494

Schratzberger M, Warwick RM (1999) Differential effects of various types of disturbances on the structure of nematode assemblages: an experimental approach. Mar Ecol Prog Ser 181:227 236

Smyth GK, Verbyla AP (1996) A conditional likelihood approach to REML in generalized linear models. J Roy Statist Soc Ser B Methodol 58:565 572

Soetart K, Vincx M, Wittoeck J, Tulkens M (1995) Meiobenthic distribution and nematode community structure in five European estuaries. Hydrobiologia 311:185 206

Strayer D (1985) The benthic micrometazoans of Mirror Lake, New Hampshire. Archiv fur Hydrobiol Suppl 72:287 426

Taniguchi H, Tokeshi M (2004) Effects of habitat com plexity on benthic assemblages in a variable environ ment. Freshw Biol 49:1164 1178

Tokeshi M (1993) Species abundance patterns and com munity structure. Adv Ecol Res 24:111 186

Tolonen KT, Hamalainen H, Holopainen IJ, Karjalainen J (2001) Influences of habitat type and environmental variables on littoral macroinvertebrate communities in a large lake system. Arch Hydrobiol 152:39 67
Traunspurger W (1991) Fischbiologie des Konigssees. Das Meiobenthos des Konigssees. Systematische und okologische Untersuchungen unter besonderer Berucksichtigung der Nematoda. Nationalpark Ber chtesgaden, Berchtesgarden, Germany, p 152

Traunspurger W (1996) Distribution of benthic nematodes in the littoral of an oligotrophic lake (Konigssee, National Park Berchtesgaden, FRG). Arch Hydrobiol 135:393 412

Traunspurger W (1997) Bathymetric, seasonal and vertical distribution of feeding types of nematodes in an oligotrophic lake. Vie et Milieu 47:1 7

Traunspurger W (2000) The biology and ecology of lotic nematodes. Freshw Biol 44:29 45

Traunspurger W (2002) Nematoda. In: Rundle SD, Rob ertson AL, Schmid Araya MJ (eds) Freshwater Mei ofauna: biology and ecology. Backhuys Publishers, Leiden, The Netherlands, pp 63104

Urban MC (2004) Disturbance heterogeneity determines freshwater metacommunity structure. Ecology 85:2971 2978

Witthoft Muhlmann A, Traunspurger W, Rothhaupt KO (2005a) Influence of river discharge and wind field on the freshwater meiofauna of a dynamic river mouth area. Arch Hydrobiol 163:307 327

Witthoft Muhlmann A, Traunspurger W, Rothhaupt KO (2005b) Meiobenthic response to river borne benthic particulate matter a microcosm experiment. Freshw Biol 50:1548 1559

Wu J, Fu C, Liang Y, Chen J (2004) Distribution of the meiofaunal community in a eutriphic shallow lake of China. Arch Hydrobiol 159:555 575

Yeates GW, Bongers T, De Goede RGM, Freckman DW, Georgieva SS (1993) Feedings habits in soil nematode families and genera an outline for soil ecologists. J Nematol 25:315 331 